\title{
Leading Change in Arsi Administrative Zone Technical and Vocational Education Training Institutions of Oromia Region, Ethiopia
}

\author{
Birhane Sime Geressu \\ Assistant Professor, School of Educational Sciences and Technology Teachers Education \\ Adama Science and Technology University, Adama, Ethiopia \\ E-mail: birhane_200@yahoo.com,birhanesime2012@gmail.com
}

\section{Doi:10.5901/jesr.2014.v4n3p109}

\begin{abstract}
The intent of this study was to examine the leadership of technical and vocational education and training (TVET) reforms in Arsi administrative Zone of Oromia Region, Ethiopia. To achieve this purpose, researcher used mixed approach research paradigm. The participants of the study include: 45 trainers, 35 board members, and 18 District officials. Moreover, 6 Deans, 6 core process owners, 2 zonal and 2 regional TVET agency experts were selected and interviewed. Questionnaires, semistructured interviews and document analysis were employed to solicit data from key informants in the study setting. Data were analyzed both through qualitative and quantitative analysis methods. The study result showed that the current TVET leaders lacks required technical creativity and innovative leadership competencies that enable them to plan, organize, communicate , guide and evaluate the reform program. Hence, the study recommend the importance of enhancing the competence of leaders through education and continuous training that enable them to tackle major problems affecting the implementation of the reform.
\end{abstract}

Keywords: Leader, technical education, change, competencies, implementation

\section{Introduction}

Organization is an open system that is in a constant interactional and interdependent relationship with its environment. The survival, growth and success of an organization depend on its ability to change its structure and process in response to dynamic forces within its own boundaries as well as in its external environment (Fullan, 1993). According to Senge (1990) change can be a reflection of one, two, or all of these different aspects. Some argue that a change in structure without a change in attitude does not "really" reflect change. Changes can also be classified along these lines in terms of the content of change: faculty contracts or merit pay, for example, relate to structural changes; collaborative management represents a new process; and becoming more intellectual environment might be an attitude change with no structural or process changes.

The scale of change has been examined through frameworks that divide the organization into understandable parts for investigation, such as individual, interpersonal, and organizational levels (Goodman, 1982). Researchers also define the focus of change. According to (Bergquist, 1992) focus of change refers to the issue of which aspects of the organization are affected by the change. A framework conceived by Tierney (1988) describes three main foci: structure, process, and attitude. Structure refers to the organizational chart, the reward system, or institutional policies and procedures. In contrast, process relates to the way people interact within existing structures. Attitude focuses on how people feel about working within the existing structures and processes of the organization. Change in attitude is also tied to change in culture (Tierney, 1988).

Structural changes are often characterized as being easier and less controversial than process or attitude changes. Integrating technology into the classroom is a structural, process, and attitude issue, but mostly reflects a process change. Student affairs staff redefining multiculturalism is an attitude change, but it may also affect structures and processes over time. It is difficult to change any one of these foci without affecting the others, but the relative emphasis on each varies with the circumstances of change (Tierney, 1988). Change requires a long-term commitment of organizational leader who is committed in establishing a clear vision, mission, developing plans, and implementing those plans or new programs effectively (Fullan, 1993). Besides, successful educational change requires the involvement of teachers, parents, community and other partners, administrators, and students to share leadership functions (Senge, 1990). 
Louis and Miles (1990) also found role expected from leaders for successful change implementation. According to them, leading successful change involves developing and managing six critical components of schooling. These are: (1) having a clear , strong, and collectively held educational vision and institutional mission ; (2) having a strong , committed professional community within the school; (3) creating learning environments that promote high standards for student achieving; (4) sustaining professional development to improve learning; (5) establishing successful partnerships with parents, health and human service agencies, businesses, universities, and other community organizations; and (6)systematic planning and implementation process for instituting needed changes. Therefore, for successful change institutional leader should encourage and support the development of cooperative school culture, with clear institution missions and processes, structures, and resources that allow educational change to flourish (Dawson, 1994). Successful institutions also should have leaders who are committed to provide high- quality learning for all students, initiating, implementing, and integrating programs that improve access to engaged teaching and learning for all students.

In general, the above discussions showed that change in educational institution is complex that requires school leader who understand the change process, learn to overcome barriers and cope with the chaos that naturally exists during the process of change. It is with this ground that the researcher finds it appropriate to investigate the competence and roles played by TVET leaders in implementing TVET reform in Arsi administrative Zone of Oromia Region, Ethiopia.

\section{Statement of the Problem}

The 2000 UNESCO and ILO's General Conference on Technical and Vocational Education and Training defines TVET as the study of technologies and related sciences, and the acquisition of practical skills, attitudes, understanding and knowledge related to occupations in various sectors of economic and social life. Emphasizing on this, UNESCO (2002:75) states the importance of technical and vocational education and training (TVET) as follows: "the aim of TVET is to produce the work qualifications skills demanded in a given social and economic context and to contribute towards the implementation of national policy with regard to employment promotion, poverty reduction, private sector promotion, increased productivity and enhanced competition in both local and global market".

In this direction, the goal of TVET is to supply skills needed in the labour market, creating competent, motivated and adaptable workforce who is capable of driving economic growth and development of the country (Middleton, Ziderman, \& Adams, 1990). Recognizing this, Ethiopian Government develops the first national TVET strategies in 2002. However, due to scarcity of resources, irrelevancy of curriculum to labour market needs, structural problem, shortage of TVET teachers and cost of TVET inputs and other related problems the objectives set for TVET were not successfully achieved(MoE, 2008).

To overcome the problem and to respond to the required skills and qualification in the labour market the previous 2002 TVET strategy was revised in early 2008. Consequently, the major objectives of the new on-going TVET reform program is to create competent, adaptable and innovative workforce, contributing to poverty reduction and socioeconomic development through facilitating demand driven, high quality TVET for all people in need of skills development (MoE,2008). However, the implementation of this reform is not effective at micro-level and this problem creates gap between macro-level planning and ground-level implementation (Shigeru, 2009). Moreover, according to regional 2010/11 performance evaluation the implementation of the reform program is under question. Besides, the preliminary information of the researcher revealed that in most TVET institutions there is a tendency of fixing to old system of managing training programs.

Hence, the purpose of study is to investigate the role played and challenges faced by TVET leaders' during the implementation of the reform program. To meet the stated purpose of the study the following basic questions were formulated as a guide for treating the problem. (1) To what extent does the current TVET reform have been implemented at institutional level? (2) What actions do TVET leaders' took during the implementation of the reform program? (3) Are current TVET leaders' competent enough to effectively implement the reform program? (4) What major factors adversely affect the implementation of TVET reform program?

\section{Scope of the Study}

To examine the extent of the implementation of TVET reform and the competence of TVET leaders in implementing TVET reform, the study was bound to 6(50\%) TVET institutions which were established before the implementation of newly designed TVET reform program. Consequently, the selected TVET institutions are Asella, Athelet Kenenisa Bekele, Arsi-Robe, Arbagugu, Bekoji, and Sagure. Even though, the study would be delimited to six TVET schools, it is 
believed that the study would still give some insights to the rest TVET institutions. The time horizon of the study was also delimited between 2008/9-2010/11 academic years.

\section{Research Methodology}

This study is aimed at assessing the expected and actual role played by TVET leaders in implementing TVET reform in Arsi administrative Zone of Oromia Region, Ethiopia. The empirical investigation is based on the mixed methods research paradigm, predominantly on the quantitative research method. In order to get first hand information, primary data was collected from TVET trainers, Woreda TVET officials, and TVET board members. Those groups were taken as research participant because they have direct relation with the issue under consideration. Accordingly, based on the number of respondents by using simple random sampling technique 45 trainers (15.73\%), 18 (75\%) District TVET officials and 35 (21.48\%) TVET board members were selected as sample respondents. In order to obtain first hand information, primary data was collected from the subjects through questionnaire and interviews. Finally, different methods of analysis relevant to each variable were employed to analyze the gathered data. The data collected in a qualitative approach were analyzed by using case by case and cross-case analysis. The raw data collected through a quantitative approach were tallied, tabulated, and analyzed by using percentage and mean.

\section{Results and Conclusion}

The main sources of information were four major groups: trainers, TVET board members, and Woreda TVET officials. The questionnaire was distributed to sampled respondents that include 45 trainers 35 TVET board members, and 18 District TVET officials. Out of the total number of questionnaire distributed among the three study groups, 43 (95.5\%) from the trainers/teachers, 31 (88.6 \%) from TVET board members, and 16 (88.9\%) from District TVET officials were filled in and returned. Moreover, 6 TVET principals, 6 core process owners, 2 Zonal and 2 Regional TVET experts were interviewed. Regarding the service years of respondents, it was observed that more than $73 \%$ of trainers have served above 6 years and 58.33\% District TVET officials have an experience less than 5 years. With respect to academic qualification, $84.44 \%$ of the trainers and $100 \%$ of principals were degree holders. However, all TVET principals in Arsi administrative zone, no one are graduated from the field of engineering. The implication, thus, is that principals were lack technical competence which may have an impact on bringing innovative ideas and leading the current reform program effectively.

\section{Level of Implementation of TVET Reform}

TVET teachers, TVET board members and Woreda TVET experts were asked to rate the level of implementation TVET reform in their respective TVET institutions. A five point scale ranging from rarely implemented (1) to fully implemented (5) was given to respondents to make their alternative choices. Accordingly, respondents rate their response on each major areas of reform.

Table I: Mean Rating on the Level of Implementation of TVET Reform

\begin{tabular}{|c|c|c|c|c|}
\hline \multirow[b]{2}{*}{ No } & \multirow[b]{2}{*}{ Areas of TVET reform } & \multicolumn{3}{|c|}{ Mean of respondents } \\
\hline & & $\begin{array}{l}\text { Teachers } \\
\mathrm{N}=43\end{array}$ & $\begin{array}{c}\text { TVET board } \\
\text { members } \mathrm{N}=31\end{array}$ & $\begin{array}{l}\text { Woreda TVET } \\
\text { officials } \mathrm{N}=16\end{array}$ \\
\hline 1 & Equal access for all target groups ensured & 2.35 & 2.32 & 1.87 \\
\hline 2 & TVET institution and enterprises starts cooperative training & 1.54 & 2.11 & 2.37 \\
\hline 3 & $\begin{array}{l}\text { Trainees have got a chance to work and learn the occupational practice in } \\
\text { a real life situation (apprenticeship training) }\end{array}$ & 1.95 & 2.33 & 2.47 \\
\hline 4 & $\begin{array}{l}\text { TVET institutions develop curricula that are based on the national } \\
\text { occupational standards }\end{array}$ & 2.33 & 2.23 & 3.77 \\
\hline 5 & curricula considers local labour market requirement & 2.11 & 2.42 & 2.59 \\
\hline 6 & TVET programmes are organized in modular fashion & 3.51 & 3.53 & 3.58 \\
\hline 7 & Modules describes an employable set of competences & 2.12 & 2.35 & 2.67 \\
\hline \multicolumn{2}{|r|}{ Overall mean } & 2.27 & 2.44 & 2.82 \\
\hline
\end{tabular}

Mean $\leq 2.50$ low; mean 2.51-3.75 average; mean 3.76 -5.00 high 
The first item of Table I, ask the opportunities of citizens to get the chance to be trained inside TVET institutions. As depicted from the table all groups of the respondents labeled access of training for all target groups was low (mean < 2.5). The document analysis and observation made at institutional level also assures that the current number of trainees are few and all TVET institutions cannot afford the training program which are needed by the applicants.

TVET principals also agree with the reality on the ground but the reason given during the interview session were inadequacy of trainers, financial resources, shops, machines, and related training materials. Furthermore, the weak link between: national development policy and the role of TVET, skills needs in industry and educational curricula; TVET institutions and Universities; and formal training and firm-based training affect the successful implementation of the reform program. Item 2, in Table I was intended to know the extent of the implementation of cooperative training between TVET institution and enterprises. To this item all group of respondents affirmed that the partnership program between TVET institution and enterprises were low.

Item 3, of Table I, deal with apprenticeship training. This is to see whether trainees have got a chance to work and learn the occupational practice in a real life situation. As observed from the table again the respondents unanimously reported that the apprenticeship training were low. This implies that TVET and industry linkage is weak which results in underutilization of resource and production of incompetent graduates to the labour market. Item 4 and 5 of Table I deal with the development of TVET curriculum that is based on the national occupational standards. On this point, however, group of respondents show difference.

According to teachers and TVET board members the current TVET curriculum developed at institutional level was not up to the expected standard and does not consider specific target group and local labour market requirement (mean value less than 2.5). But, District TVET officials argue that the current TVET curricula developed at TVET institutions in average it goes along with national occupational standard and satisfies the need for skilled manpower in the local labour market (mean= 3.77). The reason for this idea difference between respondents may be the proximity of respondents to the task. That is teachers and TVET board members might have more understanding on the issue than District TVET experts.

TVET principals also support the idea of teachers and TVET board members. According to them the current TVET curriculum developed at institutional level was not up to the expected standard. The reason given by the principals was the low competence of teachers to adapt and develop curricula that satisfies the need of the labour market. On the other hand, through open ended question teachers responded that TVET principals lack technical skill to guide the general preparation and implementation of TVET curriculum.

The $6^{\text {th }}$ and $7^{\text {th }}$ items of Table I ask about the organization of TVET programs and the description of modules. As depicted from the table, all groups of the respondents labeled that the current TVET program are organized in modular fashion. However, for the teachers and TVET board members module prepared at institutional level does not fully describe employable set of competences. Nevertheless, may be for the same reason stated above District TVET experts argues differently from teachers and TVET board members. For them the module developed at TVET institution level partially contains and describes an employable set of competences. The interview made with TVET principals affirmed that the status of the TVET module in containing competency needed in the labour market were low. The major reason given by TVET leaders was teachers' lack practical competence (industrial experience) to include all competence needed in the world of work. According to them teachers seems competent in the area of subject area and TVET curriculum.

From the response given for open-ended questions raised for trainers, board members and District TVET officials, it is possible to infer that the integration among formal, informal and non-formal training, the world of work and TVET system and the involvement of stakeholders was low. Besides, industry lacks awareness to provide in-company and cooperative training for trainees. Generally, the finding implies that the designed TVET reform program was not fully implemented. The reasons given were: TVET trainers lack capacity and practical competence in developing relevant curricula, weak cooperative and apprenticeship training, and inability to develop curricula that consider local labour market. However, many structural reform programs were implemented almost in all sampled TVET institutions.

\section{Competencies of TVET Leaders in Implementing TVET Reform}

Changes in organizations are more and more common. They appear at faster pace and employees are expected to be even more adaptable. Besides, leaders should play an important role in setting an example for all those values, behaviors and considerations expected from employees. According to Bennis (1987; cited in Yukl (2006) leadership competencies are the clusters of vision and goal setting, interpersonal and technical skills regarding the specifics of the organizations in which the leaders work. It involves, integrity, communication, developing others, result orientation, 
change management, problem solving, strategic thinking, customer focus and team leadership are categorized under leadership competences. In this regard, respondents were asked to point up the competences of current TVET leaders' in implementing TVET reform. According to the result obtained, Table II item 1-4, the response given by teachers, TVET board members and District TVET officials were more or less the same. Accordingly, Table II, item 1, deals in assessing the creativity and innovative competence of current TVET leaders. As it is seen in table below majority of respondents argue that the current TVET leaders are weak in introducing new innovative ideas which is model for their followers and facilitate the achievement of intended reform program. More specifically, it was responded that leaders' in Arsi zone TVET institutions somewhat encourage change implementers and their supporters to innovate new idea; however, they do not adequately challenge their follower to search new knowledge and to be innovative problem solver.

To respond to the changing skills needs of the economy, and to be proactive in regard to technological and industrial change, TVET leaders need to be more independent from interference of various authorities (UNESCO, 2002). Related to this issue respondents were asked questions and the response goes with the responses given for Table 4 that indicates as leaders lack technical competence to effectively guide and monitor technical activities and implement the change process. Furthermore, Item 2, leadership behavioral competence was forwarded for respondents. Without major difference almost all respondents argue that current TVET leaders frequently use opportunities to work with followers, facilitate communication between people in the institution and encourage sense of mutual accountability.

Besides, they were competent enough to effectively identify and manages potential conflict within and works to resolve conflict among team members. Furthermore, majority of respondents argue that the current TVET leaders coordinate efforts toward goal achievement and have sense of accomplishment of TVET reform. However, they lack to develop and implement visible plan, to organize, and efficiently use scarce resources.

Table II: Mean Rating on the Competencies of TVET Leaders in Implementing TVET Reform

\begin{tabular}{|c|c|c|c|c|}
\hline \multirow[b]{2}{*}{ No. } & \multirow[b]{2}{*}{ Behavioral leadership competences } & \multicolumn{3}{|c|}{ Mean of respondents } \\
\hline & & Teachers & $\begin{array}{l}\text { TVET board } \\
\text { members }\end{array}$ & $\begin{array}{l}\text { Woreda TVET } \\
\text { officials }\end{array}$ \\
\hline \multirow[t]{4}{*}{1} & Creativity and innovation competences & & & \\
\hline & $\begin{array}{l}\text { - Encourage others to innovate new idea that enables the institution to } \\
\text { implement the intended change }\end{array}$ & 2.81 & 2.97 & 3.24 \\
\hline & - Challenging followers to be innovative problem solvers & 1.39 & 2.11 & 2.46 \\
\hline & - Search for new knowledge & 1.71 & 1.91 & 2.33 \\
\hline \multirow[t]{4}{*}{2} & Team work and cooperation competence & & & \\
\hline & - Frequently uses opportunities to work with others & 3.44 & 3.89 & 4.04 \\
\hline & - Facilitate communication between people & 4.14 & 4.59 & 4.64 \\
\hline & - Encourage sense of mutual accountability & 4.34 & 4.89 & 4.74 \\
\hline \multirow[t]{3}{*}{3} & Conflict management competence & & & \\
\hline & - Effectively identifies and manages potential conflict within & 3.76 & 4.01 & 4.53 \\
\hline & - Works to resolve conflict among team members & 4.21 & 4.52 & 4.77 \\
\hline \multirow[t]{8}{*}{4} & Managerial competence & & & \\
\hline & - Develop visible and relevant plan & 1.77 & 2.12 & 2.55 \\
\hline & - Organize resources & 1.12 & 2.13 & 2.45 \\
\hline & - Generate and communicate the vision & 2.63 & 3.98 & 3.65 \\
\hline & - Have technical competence regarding expected managerial task & 1.91 & 1.87 & 1.52 \\
\hline & - Make sound decision & 2.87 & 2.99 & 3.34 \\
\hline & - Have sense of accomplishment/ achievement oriented & 3.55 & 3.53 & 3.53 \\
\hline & Average & 2.83 & 3.25 & 3.42 \\
\hline
\end{tabular}

$\mathrm{N}=75$ Mean $\leq 2.50$ low; mean 2.51-3.75 average; mean 3.76 -5.00 high

Moreover, in the open ended questionnaires $73.3 \%$ interviewees' anonymously agree that the reform program was not fully implemented. The reason for unsuccessfulness in the implementation of the current TVET reform program was lack of adequate and relevant leadership competencies such as coaching, empowering, building the commitment of employees, developing learning organization, creating cultures for stakeholders' collaboration and building and strengthening teamwork. In addition, inability of the leader to introduce new innovative ideas and ineffective procedures followed by leaders during the implementation of the reform program affects the realization of TVET reform program. 
In general, from the result it is possible to say that the current TVET leaders have human leadership skill to manage the human side. However, lack of technical skill hinders them not to plan, implement, communicate, control, monitor and evaluate technical matters.

\section{Leaders' Actions and TVET Reform Implementation}

As shown in Table III below, a question was also presented to respondents to indicate the action taken by TVET leaders during the implementation of change. As the data in Table III, reveals in item 1.1 and 1.2, majority of respondents declared that the extent of knowing supporters and opponents of the reform and forming collision with the supporters of the change by TVET leaders was average with mean value 3.18 and 3.34 respectively. However, both group of respondents argue TVET leaders assign taskforce to guide implementation (mean= 3.65). However, the individuals assigned to implement the process of change were not competent enough (mean=2.24).

In item 1.5 and 1.6 of Table III, respondents were asked on the ability of TVET leaders in making dramatic change and monitoring the progress of change. In this regard respondents rated that the capacity of current TVET leaders in bringing dramatic and symbolic change is average (mean= 2.76) but they monitor the progress of change (mean=3.54). Table III below generally indicates that all groups of respondents believe that organizational or structural action taken by TVET leaders during the implementation of change was average (mean=3.12).

Table III: Actions taken by TVET Leaders during the Implementation of TVET Reform

\begin{tabular}{|c|l|c|}
\hline No. & \multicolumn{1}{|c|}{ Extent of action taken by the leader during the implementation of reform } & Mean value \\
\hline 1 & Political / Organizational actions & \\
\hline 1.1 & Identifies likely supporters and opponents of the change & 3.18 \\
\hline 1.2 & Build a broad coalition to support the change & 3.34 \\
\hline 1.3 & Fill key positions with competent change agents & 2.24 \\
\hline 1.4 & Use taskforce to guide implementation & 3.65 \\
\hline 1.5 & Make dramatic and symbolic change & 2.76 \\
\hline 1.6 & Monitor the progress of change & 3.54 \\
\hline & Overall mean & 3.12 \\
\hline 2 & People-oriented actions & 3.63 \\
\hline 2.1 & Create a sense of urgency about the need for change & 2.24 \\
\hline 2.2 & Prepare people to adjust to change & 2.09 \\
\hline 2.3 & Help people deal with the pain of change & 2.35 \\
\hline 2.4 & Provides opportunities for early success & 3.62 \\
\hline 2.5 & Keep people informed about the progress of change & 2.32 \\
\hline 2.6 & Demonstrate continued commitment to the change & 2.17 \\
\hline 2.7 & Empower people to implement the change & 2.63 \\
\hline & Overall mean & \\
\hline
\end{tabular}

$\mathrm{N}=75$ Mean $\leq 2.50$ low; mean 2.51-3.75 average; mean 3.76 -5.00 high

To this end item 2 of Table III was posed to respondents to rate people oriented action taken by TVET leaders during the implementation of change. As depicted from the table, in average all respondents argue that TVET leaders inform stakeholder about the progress of change and create a sense of urgency about the need for change with mean value 3.62 and 3.63 respectively. However, the extent of preparing to adjust them self to change, helping people to deal with the pain of change, providing an opportunities for early success, demonstrating continued commitment to the change and empowering people to implement the change was low.

In short, the finding implies that no satisfactory organizational and people-oriented measures were taken by current TVET leaders during the implementation of TVET reform (mean=3.12 and 2.63). As a result the success of efforts to transform the organizational reform will be under question.

\section{Factors Affecting the Implementation of TVET Reform}

In order to survive and thrive and to adapt to the changing conditions all organizations need to be changed. Unfortunately, due to the existence of different barriers every change process cannot leads to the expected results 
(Conner, 1995; cited in Yukl, 2006). Change can be resisted by individuals or organization itself. Concomitant with this, questions related to factors hindering the effective implementation of TVET reform was posed to all groups of respondents. In general, respondents were asked to assess items with alternative ranging from "not at all" "to always".

Accordingly, respondents argue that the major reason hindering leaders not to implement the reform program effectively are: lack of proper communication regarding the importance and urgency of change (84\%), rapidity and extent of change (76\%), fear to loss of power (82.67\%), job insecurity (93.33\%), and fear of unknown (78.67\%). Also, lack of involvement of employee in planning phase (97.33\%), ignoring the already established organizational culture (96\%), and assumption of followers that the present situation is satisfactory (69.33\%), and lack of trust and respect in the change initiator (86.67\%).

Table IV: Rating on factors hindering the effective implementation of TVET Reform ( $N=75)$

\begin{tabular}{|l|c|c|c|c|c|c|}
\hline \multirow{2}{*}{ Factors } & \multicolumn{2}{|c|}{ Not at all } & \multicolumn{2}{c|}{ Occasionally } & \multicolumn{2}{c|}{ always } \\
\cline { 2 - 8 } & No & $\%$ & No. & $\%$ & No & $\%$ \\
\hline Lack of proper communication regarding a change & 1 & 1.33 & 11 & 14.67 & 63 & 84 \\
\hline Rapidity and extent of change & 3 & 4 & 15 & 20 & 57 & 76 \\
\hline employees are not involved in planning change & & & 2 & 2.67 & 63 & 97.33 \\
\hline Job insecurity & 1 & 1.33 & 4 & 5.33 & 70 & 93.33 \\
\hline Fear of unknown & 4 & 5.33 & 12 & 16 & 59 & 78.67 \\
\hline Habit pattern of the work group are ignored & & & 3 & 4 & 72 & 96 \\
\hline The present situation seems satisfactory & 11 & 14.67 & 12 & 16 & 52 & 69.33 \\
\hline Lack of trust and respect in the change initiator & 3 & 4 & 7 & 9.33 & 65 & 86.67 \\
\hline lack of trust ( on the employee side) & 52 & 69.33 & 21 & 28 & 2 & 2.67 \\
\hline Loss of power ( on the leader side) & 11 & 14.67 & 2 & 2.67 & 62 & 82.67 \\
\hline Leaders lack technical skill & & & 1 & 1.33 & 74 & 98.67 \\
\hline Inadequacy of training budget & 4 & 5.33 & 4 & 5.33 & 67 & 89.33 \\
\hline Insufficiency of physical facilities & & & 3 & 4 & 72 & 96 \\
\hline Institutional culture cannot encourage risk taking & 73 & 97.33 & 2 & 2.67 & & \\
\hline Lack of institution rewards for being innovative & 69 & 92 & 6 & 8 & & \\
\hline
\end{tabular}

There are various types of organizational change. Some of them are revolutionary, evolutionary and planned change. While organizations needs to implement one of those types of change resistance from members of the organization are expected. Therefore, before implementing change organizational leaders should assure organizations readiness for change ( Susanto, 2008).

Concomitant with this, other questions was posed to respondents with the intention to identify the level of organizations readiness for change. As depicted from Table IV, as per $97.3 \%$ of the respondents, the current institutional environment was not motivating school community to be involved in planning and implement the reform program by taking risk. This may cause dissatisfaction of employee.

Organizations are continually confronted with the need to implement changes in strategy, structure, process and culture. This requires encouraging and rewarding individuals and groups who are innovative. In this regard, respondents were asked to rate about the institutional reward for innovative individuals and teams during the introduction and implementation of TVET reform. Accordingly, as it was seen from Table IV, institutions were not ready to reward individuals who brings innovative ideas and who are committed to implement the reform program. This shows that the institution climate cannot value effort and performance of trainers which may create resistance and dissatisfaction.

Leading change in any organization including TVET institutions requires all leadership skills especially technical skills, and skill to create vision, justifying benefits of altering current organizational cultures and supporting the culture that is adaptable and can readily accept change (Beer, 1988). With this concept a question was forwarded to respondents in Table IV to examine status of leader's technical skills. As the data in Table IV shows, almost all respondents (98.67 \%) rated that TVET leader's technical skills as low. The unanimity of the respondents indicates that the dimension of the problem. Besides, inadequacy of budget and training facilities affects the implementation of TVET reform.

During interview session TVET principals, core process owners and Woreda TVET officials' agree with major challenges rated by trainers'. They also confirmed as they lack technical skill to plan, monitor and evaluate technical activities carried out by trainers. On the contrary, they argue that the major problem they encounter during the 
implementation of change/ reform was the lack of competence of trainers. According to them TVET trainers assume the competence assessment as waste of time and are less committed to copy, accumulate and transfer technology. In addition, trainers consider skill gap training as means of fringe benefits rather than improving their skill. Generally, trainers lack practical technical skills to equip trainees to work and learn in real life situation and to develop curricula in accordance with the national occupational standards and local labour market requirements.

Besides, TVET principals said that external factors such as continuous change in technology and labour market needs, political pressure without adequate budgetary support, high expectation of society and in some case silence and individualism hinders them not to implement the reform program as it was intended. Moreover, industries show less belongingness for outcome based training, low participation in competence assessment and preparation of occupational standard and assume that TVET is the duty of government. Moreover, trainees' bearing in mind center of competence $(\mathrm{CoC})$ as their obstacle to determine their destiny and they are not taking into consideration cooperative training as the part of their regular training session.

In general, the implementation of current TVET reform was affected by the institutional culture, low technical competence of TVET leaders, internal and external resistance to change, inadequacy of resources and unreadness of TVET institution to change. In addition, it is possible to conclude that the rate of employees to resist change was high. The major reasons were unreadness of organization for change, lack of involvement, inadequacy of proper communication and fear of consequences from employee and leaders side.

\section{Conclusion}

Organization consists of people, whose perceptions can facilitate or undermine the effectiveness of the change program. In a change environment, the role of leader is very critical in inspiring people to support and participate in the change initiatives and in making organization ready for change process. Change also need competent change agent who able to generate new vision and communicate it effectively. Besides, leaders need to help people to clearly see their role in new ways of doing things in order to build commitment to change. However, the results of the investigation show that the current TVET leaders were not competent enough to introduce and implement the reform program efficiently in challenging situation. Besides, they did not made the institution to be ready for change, try to minimize employee resistance to change, and effectively utilizing resources. Moreover, from the data obtained it is possible to say that the current TVET leaders in Arsi Administrative Zone lack required technical, creativity and innovative leadership competences that enable them to plan, organize, communicate, guide, control, monitor and evaluate the reform program.

Besides, they were not frequently took relevant organizational and people-oriented actions to implement the reform program. As a result the reform program was not implemented as intended. In addition, concerned bodies were not identifying leaders problem and arrange training program that enables TVET leaders in Arsi zone to effectively implement the change.

\section{The Way Foreword}

Leading change in an organization requires leadership competences such as creating a vision of the future, justifying the benefits of altering the current systems or processes, and supporting an environment culture that is adaptable and can readily accept change. In general, to increase the rate of the implementation of change and to overcome new challenges facing them current TVET leaders need to develop their skill and competence through formal training, education, coaching, mentoring and through self exercise and experience.

Therefore, as much as possible Woreda TVET office needs to assign TVET leaders who have required technical and managerial skills and try to provide a chance for newly assigned leaders to get continuous and relevant on-the-job and off- the-job formal training that enable TVET leaders to tackle major problems affecting the implementation of the reform which in turn improves the performance of the institutions. Moreover, they should provide supervisory and professional support through periodic monitoring and evaluation of the achievement.

Besides, TVET leaders should make an organization ready for change by articulating their vision and making the organizational climate conducive for change. In addition, they should strengthen the partnership program with concerned stakeholders to minimize different factors that affect the effective implementation of the reform program. 


\section{References}

Bergquist, W. (1998). The postmodern challenge: Changing our community colleges. In J. S. Levine (Ed.), Organizational change in the community college: A ripple or a sea of change. San Francisco: Jossey-Bass.

Creswell, J.W. (2009). Research Design: Qualitative, quantitative and mixed methods approaches. (3rd ed) Los Angeles: SAGE Publications Inc.

Dawson, P. (1994). Organizational change: A processual approach. London: Paul Chapman.

Goodman, P. S. (1982). Change in organizations: New perspectives on theory, research, and practice. San Francisco: Jossey-Bass.

Loiuis, K.S. and Miles, M.B. (1992). Improving the urban high School. What works and why. London: Cassell.

Middleton,J. ; Ziderman,A.; Adams, A. (1990). Making vocational training effective. In: Finance and development, 27(1), 30-32

MoE (2008). National Technical and Vocational Education and Training (TVET) Strategy. Addis Ababa. Final

Senge, P. (1990). The fifth discipline: The art and practice of the learning organization. New York: Doubleday.

Shigeru,(2009). Reforming Ethiopia's TVET Validity and Feasibility in the Field of ICT in Southern Tigray Region. St. Bernard University

Susanto, A. (2008). Organizational Readiness for Change. Jakarta, Tarumanagara University:

Tierney, W. (1988). Organizational culture in higher education. Journal of Higher Education, 59, 2-21. 146

UNESCO (2000b). Technical and Vocational Education and Training In the 21 st century. New Roles and challenges for Guidance and Counseling. Paris: UNESCO.

UNESCO (2002). Technical and Vocational Education and Training for Twenty-first Century: UNESCO and ILO Recommendations: Paris: UNESCO.

Yukl,G. (2006). Leadership in Organization. New Jersey. Prentice Hall 
